Geosistemy perehodnykh zon = Geosystems of Transition Zones / Геосистемы переходных зон

Content is available under the Creative Commons Attribution 4.0 International License (CC BY 4.0)

2020, vol. 4, No. 4, pp. 393-446

URL: http://journal.imgg.ru/archive.html ; https://elibrary.ru/title about.asp?id=64191

https://doi.org/10.30730/gtrz.2020.4.4.393-416.417-446

\title{
On the stress drop in North Eurasia earthquakes source-sites versus specific seismic energy
}

Nailia A. Sycheva ${ }^{1}$, Leonid M. Bogomolov*2

${ }^{1}$ Research Station RAS in Bishkek city, Kyrgyzstan

2 Institute of Marine Geology and Geophysics, FEB RAS, Yuzhno-Sakhalinsk, Russia

*E-mail: bleom@mail.ru

\section{Abstract PDF ENG Резюме PDF RUS $\quad$ Full text PDF RUS \& ENG}

Abstract. A generalization of the results on the stress drop and the specific seismic energy for the earthquakes in Northern Eurasia has been made. The relationship of these parameters with the seismic moment and the magnitude has been analyzed. Detailed studies for the Northern Tien Shan (Bishkek geodynamic polygon) were carried out, the values of the dynamic parameters of the sources for 183 earthquakes of various energy classes $(K=8.7-14.8)$ were obtained: angular frequency, spectral density parameter, scalar seismic moment, source radius, stress drop level, seismic energy and specific seismic energy. Two models have been used to compute the source radius and the stress drop - the Brune approach and the improved Madariaga-Kaneko-Shearer model. For relatively weak events, a power-law dependence (regression) of the stress drop on the scalar seismic moment M0 has been identified, that complies with the results on the power-law dependence of the specific seismic energy on $\mathrm{M} 0$ in a number of other regions of Northern Eurasia. The relationship between the type of source movement and the stress drop level has been noted as well.

\section{Keywords:}

earthquake source, magnitude, seismic moment, stress drop, specific seismic energy, scaling dependence

For citation: Sycheva N.A., Bogomolov L.M. On the stress drop in North Eurasia earthquakes source-sites versus specific seismic energy. Geosistemy perehodnykh zon = Geosystems of Transition Zones, 2020, vol. 4, no. 4, pp. 393-446. (In Russ. \& Engl.). https://doi.org/10.30730/gtrz.2020.4.4.393-416.417-446

Для цитирования: Сычева Н.А., Богомолов Л.М. О сброшенных напряжениях в очагах землетрясений Северной Евразии и приведенной сейсмической энергии. Геосистемы переходных зон, 2020, т. 4, № 4, с. 393-446. (На рус. и англ. яз.). https://doi.org/10.30730/gtrz.2020.4.4.393-416.417-446

\section{References (84 bibl.)}

1. Abercrombie R. E., Leary P. 1993. Source parameters of small earthquakes recorded at $2.5 \mathrm{~km}$ depth, Cajon Pass Southern California: implications for earthquake scaling. Geophysical Research Letters, 20(14): 1511-1514.

2. Abercrombie R.E., Rice J.R. 2005. Can observations of earthquake scaling constrain slip weakening? Geophysical J. International, 162: 406-424. https://doi.org/10.1111/j.1365-246x.2005.02579.x

3. Aki K., Richards P. 1983. Kolichestvennaya seysmologiya. Teoriya i metody [Quantitative seismology. Theory and methods]. Moscow: Mir Publ., vol. 1-2, 880 p. (In Russ.).

4. Allmann B.P., Shearer P.M. 2009. Global variations of stress drop for moderate to large earthquakes. J. of Geophysical Research: Solid Earth, 114, B01310. https://doi.org/10.1029/2008JB005821

5. Baltay A., Ide S., Prieto G., Beroza G. 2011. Variability in earthquake stress drop and apparent stress. Geophysical Research Letters, 38(6). https://doi.org/10.1029/2011GL046698

6. Besedina A.N., Kocharyan G.G., Kishkina S.B. 2015. Effect of deformation properties of discontinuities on sources of mining-induced seismicity in rocks. Part I: In situ observations. J. of Mining Science, 51(4): 707-717. https://doi.org/10.1134/s1062739115040078

7. Boatwright J. 1980. Spectral theory for circular seismic sources: Simple estimates of source dimension dynamic stress drop and radiated energy. Bull. of the Seismological Society of America, 70: 1-28.

8. Bogomolov L.M. 2013. Search for new approaches to explain mechanisms of interrelations between seismicity and electromagnetic effects. Vestnik DVO RAN = Vestnik of the FEB RAS, 3: 12-18.

9. Bogomolov L.M., Avagimov A.A., Sycheva N.A., Bragin V.D. et al. 2003. On the interrelation between week seismicity and sounding electric impacts at Bishkek geodynamic testing place. In: Problems of destructure earthquake disaster prevention. Almaty-Evero, 175-183.

10. Bogomolov L.M., Sycheva N.A., Zakupin A.S., Kamenev P.A., Sychev V.N. 2015. Raspredelenie spada napryazheniy v ochagakh zemletryaseniy i proyavleniya triggernykh effektov [Stress drop distribution in sources of earthquakes and trigger effects manifestation]. In.: Triggernye effekty v geosistemakh (Moskva, 16-19 yunya 2015 g.): Materialy tret'ego 
Vserossiyskogo seminara-soveshchaniya [Trigger effects in geosystems (Moscow, 16-19 June, 2015): Proceedings of the Third All-Russian workshop-meeting], IDG RAN [IDG RAS]. Moscow: GEOS, 48-56. (In Russ.).

11. Boore D.M. 2003. Simulation of ground motion using the stochastic method. Pure and Applied Geophysics, 160(3): 635676. https://doi.org/10.1007/pl00012553

12. Brune J.N. 1970. Tectonic stress and the spectra of seismic shear waves from earthquakes. J. of Geophysical Research, 75(26): 4997-5009. https://doi.org/10.1029/jb075i026p04997

13. Brune J.N. 1971. Corrections. J. of Geophysical Research, 76(20): 5002. https://doi.org/10.1029/jb076i020p05002

14. Burymskaya R.N. 2001. [Radiation spectral content and the source parameters of earthquake in the northwestern Pacific during 1969-1996]. In: A.I. Ivashchenko (ed.). Dinamika ochagovykh zon i prognozirovanie sil'nykh zemletryaseniy severozapada Tikhogo okeana [Dynamics of source zones and forecast of the string earthquakes in the northwestern Pacific]. Yuzhno-Sakhalinsk: IMGiG DVO RAN [Institute of Marine Geology and Geophysics], vol. 1: 48-67. (In Russ.).

15. Candela T., Renard F., Bouchon M., Schmittbuhl J., Brodsky E.E. 2011. Stress drop during earthquakes: effect of fault roughness scaling. Bull. of the Seismological Society of America, 101(5): 2369-2387. https://doi.org/10.1785/0120100298

16. Chediya O.K. 1986. Morfostruktury i noveyshiy tektogenez Tyan'-Shanya [Morphostructures and recent tectogenesis of Tien-Shan]. Frunze: Ilim, 315 p. (In Russ.).

17. Choy G.L., Boatwright J.L. 1995. Global patterns of radiated seismic energy and apparent stress. J. of Geophysical Research: Solid Earth, 100(B9): 18205-18228. https://doi.org/10.1029/95jb01969

18. Choy G.L., McGarr A., Kirby S.H., Boatwright J. 2006. An overview of the global variability in radiated energy and apparent stress. In: Earthquakes: radiated energy and the physics of faulting. AGU, 43-57. https://doi.org/10.1029/170gm06

19. Cotton F., Archuleta R., Causse M. 2013. What is sigma of the stress drop? Seismological Research Letters, 84(1): 42-48. https://doi.org/10.1785/0220120087

20. Dobrynina A.A. 2009. Source parameters of the earthquakes of the Baikal rift system. Izvestiya, Physics of the Solid Earth, 45(12): 1093-1109. https://doi.org/10.1134/s1069351309120064

21. Domański B., Gibowicz S. 2008. Comparison of source parameters estimated in the frequency and time domains for seismic events at the Rudna copper mine, Poland. Acta Geophysica, 56: 324-343. https://doi.org/10.2478/s11600-008-0014-1

22. Eshelby J.D. 1957. The determination of elastic field of an ellipsoidal inclusion and related problems. Proceedings of the Royal Society of London, A241(1226): 376-396. https://doi.org/10.1098/rspa.1957.0133

23. Fehler M.C., Phillips W.S. 1991. Simultaneous inversion for $Q$ and source parameters of microearthquakes accompanying hydraulic fracturing in granitic rock. Bull. of the Seismological Society of America, 81(2): 553-575.

24. Gibowicz S.J., Kijko A. 1994. An introduction to mining seismology. San Diego: Academic Press, 399 p.

25. Gibowicz S., Young R., Talebi S., Rawlence D. 1991. Source parameters of seismic events at the Underground Research Laboratory in Manitoba, Canada: Scaling relations for events with moment magnitude smaller than 2. Bull. of the Seismological Society of America, 81: 1157-1182.

26. Hanks T., Kanamori H. 1979. A moment magnitude scale. J. of Geophysical Research: Solid Earth, 84: 2348-2350.

27. Hua W., Chen Z., Zheng S. 2013. Source parameters and scaling relations for reservoir induced seismicity in the Longtan reservoir area. Pure and Applied Geophysics, 170(5): 767-783.

28. Keylis-Borok V.I., Pisarenko V.F., Solov'ev S.L. et al. 1979. [Mass determination of focal mechanisms of earthquakes on a computer]. In.: Teoriya $i$ analiz seysmologicheskikh nablyudeniy [Theory and analysis of seismological observations]. Moscow: Nauka Publ., 45-59. (Vychislitel'naya seysmologiya [Computational seismology]; vol. 12). (In Russ.).

29. Kocharyan G.G. 2012. [On radiating efficiency of earthquakes (example of geomechanical interpretation of seismological monitoring data)]. Dinamicheskie protsessy v geosferakh [Dynamic processes in the geospheres], 3: 36-47. (In Russ.).

30. Kocharyan G.G. 2014. Scale effect in seismotectonics. Geodynamics \& Tectonophysics, 5(2): 353-385. https://doi.org/10.5800/gt-2014-5-2-0133

31. Kocharyan G.G. 2016. Geomechanics of faults. Moscow: GEOS, 424 p. (In Russ.).

32. Kocharyan G.G., Markov V.K., Ostapchuk A.A., Pavlov D.V. 2014. Mesomechanics of shear resistance along a filled crack. Physical Mesomechanics, 17(2): 123-133.

33. Kocharyan G. G., Ivanchenko G. N., Kishkina S. B. 2016. Energy radiated by seismic events of different scales and geneses. Izvestiya, Physics of the Solid Earth, 52(4): 606-620. https://doi.org/10.1134/s1069351316040030

34. Kostrov B.V. 1975. Mekhanika ochaga tektonicheskogo zemletryaseniya [Mechanics of the source of tectonic earthquake]. Moscow: Nauka, 175 p. (In Russ.).

35. Landau L.D., Livshits E.M. 1988. [Theoretical physics: handbook]. Vol. 6: [Hydrodynamics]. 4 ed. Moscow: Nauka, 736 p. (In Russ.).

36. Lukk A.A., Yunga S.L. 1979. Seysmotektonicheskaya deformatsiya Garmskogo rayona [Seismotectonic deformation of Garm region]. Izvestiya AN SSSR, Fizika Zemli, 10: 24-43. (In Russ.).

37. Malovichko A.A., Malovichko D.A. 2010. [Estimation of power and deformation characteristics of the sources of seismic events]. In.: Metody i sistemy seysmodeformatsionnogo monitoringa tekhnogennykh zemletryaseniy i gornykh udarov [Methods and systems of seismic deformation monitoring of anthropogenic earthquakes and rock bumps]. Novosibirsk, vol. 2: 66-92. (In Russ.).

38. Moskvina A.G. 1969a. [The displacement field of elastic waves formed by propagating dislocation]. Izvestiya AN SSSR. Fizika Zemli, 6: 3-10. (In Russ.).

39. Moskvina A.G. 1969b. [Studies of the displacement fields of elastic waves depending on characteristics of earthquake source]. Izvestiya AN SSSR, Fizika Zemli, 9: 3-16. (In Russ.).

40. Pustovitenko B.G., Merger E.A., Pustovitenko A.A. 2013. [Dynamic parameters of the earthquake foci of Crimea according to digital seismic stations]. Geofizicheskiy Zhurnal = Geophysical Journal, 5: 172-186. (In Russ.).

41. Rautian T.G., Khalturin V.I. 1991. [Focal spectra of earthquakes]. In.: Zemletryaseniya i protsessy ikh podgotovki [Earthquakes and their processes of their preparation]. Moscow: Nauka, 82-93.

42. Rebetsky Y.L., Kuzikov S.I. 2016. Active faults of the Northern Tien Shan: tectonophysical zoning of seismic risk. Russian Geology and Geophysics, 57(6): 967-983. https://doi.org/10.1016/j.rgg.2016.05.004 
43. Riznichenko Yu.V. 1985. Problemy seysmologii: Izbrannye trudy [Problems of seismology: Selected papers]. Moscow: Nauka, $408 p$.

44. Rodkin M.V. 2001a. [The problem of the earthquake source physics: models and contradictions]. Fizika Zemli $=$ Izvestiya, Physics of the Solid Earth, 8: 42-52.

45. Rodkin M.V. 2001b. [Statistics of apparent stresses in relation to the origin of an earthquake source]. Fizika Zemli = Izvestiya, Physics of the Solid Earth, 8: 53-63.

46. Sychev V.N., Bogomolov L.M., Rybin A.K., Sycheva N.A. 2010. [The influence of electromagnetic soundings of the crust on the seismic regime of the territory of Bishkek geodynamic test site]. In: Triggernye effekty $v$ geosistemakh: Materialy Vseros. seminara-soveshch., Moskva, 22-24 iyunya 2010 goda [Trigger effects in geosystems: Proceedings of All-Russian workshopmeeting, Moscow, 22-24 June, 2010]. Moscow: GEOS, 316-326.

47. Sychev V.N., Bogomolov L.M., Sycheva N.A. 2012. [On the question of statistical reliability of seismic response by experimental soundings of the earth's crust at the Bishkek geodynamic test site]. In.: Pyatyy Mezhdunarodnyy simpozium, 19-24 iyunya, 2011 goda "Sovremennye problemy geodinamiki i geoekologii vnutrikontinental'nykh orogenov» [Proceedings of the 5th International Symposium "Modern problems of geodynamics and geoecology of intracontinental orogens", 19-24 June, 2011]. Bishkek, vol. 1: 273-280.

48. Sycheva N.A. 2016. [Kyrgyz seismological network KNET]. Vestnik KRSU [Bulletin of KRSU], 16(5): 175-183.

49. Sycheva N.A. 2020. Seismic momeDint tensor and dynamic parameters of earthquakes in the Central Tien Shan: translation. Geosistemy perehodnykh zon = Geosystems of Transition Zones, 4(2): 178-209. https://doi.org/10.30730/gtrz.2020.4.2.178-191.192-209

50. Sycheva N.A., Bogomolov L.M. 2014. Stress drop in the sources of intermediate-magnitude earthquakes in northern Tien Shan. Izvestiya, Physics of the Solid Earth, 50(3): 415-426. https://doi.org/10.1134/s1069351314030112

51. Sycheva N.A., Bogomolov L.M. 2016. Patterns of stress drop in earthquakes of the Northern Tien Shan. Russian Geology and Geophysics, 57(11): 1635-1645. https://doi.org/10.1016/j.rgg.2016.10.009

52. Sycheva N.A., Mansurov A.N. 2017. Comparison of crustal deformation rates estimated from seismic and GPS data on the Bishkek Geodynamic Polygon. Geodinamika i tektonofizika = Geodynamics \& Tectonophysics, 8(4): 809-825. https://doi.org/10.5800/gt-2017-8-4-0318

53. Sycheva N.A., Bogomolov L.M., Mukhamadeeva V.A., Yunga S.L. 2005. Determination of seismotectonic crustal strains in the North Tien Shan using focal mechanisms from data of the KNET digital seismic network. Izvestiya. Physics of the Solid Earth, 41(11): 916-930.

54. Sycheva N.A., Bogomolov L.M., Sychev V.N., Kostuk A.D. 2009. Intensity of seismotectonic deformations as the indicator of dynamic processes in earth crust (on Tien-Shan example). Geofizicheskie issledovaniya [Geophysical research], 10(2): 3746. (In Russ.).

55. Ide S., Beroza G.C., Prejean S.G., Ellsworth W.L. 2003. Apparent break in earthquake scaling due to path and site effects on deep borehole recordings. J. of Geophysical Research: Solid Earth, 108(B5): 2271. https://doi.org/10.1029/2001JB001617

56. Kanamori H. 1977. The Energy Release in Great Earthquakes. J. of Geophysical Research, 82(20): $2981-2987$. https://doi.org/10.1029/jb082i020p02981

57. Kaneko Y, Shearer P.M. 2014. Seismic source spectra and estimated stress drop derived from cohesive-zone models of circular subshear rupture. Geophysical J. International, 197(2): 1002-1015. https://doi.org/10.1093/gji/ggu030

58. Kwiatek G., Ben-Zion Y. 2013. Assessment of $P$ and $S$ wave energy radiated from very small shear-tensile seismic events in a deep South African mine. J. of Geophysical Research: Solid Earth, 118(7): 3630-3641. https://doi.org/10.1002/jgrb.50274

59. Kwiatek G., Plenkers K., Dresen G. et al. 2011. Source parameters of picoseismicity recorded at Mponeng deep gold mine, South Africa: implications for scaling relations. Bull. of the Seismological Society of America, 101(6): 2592-2608. https://doi.org/10.1785/0120110094

60. Lancieri M., Madariaga R., Bonilla F. 2012. Spectral scaling of the aftershocks of the Tocopilla 2007 earthquake in northern Chile. Geophysical J. International, 189: 469-480. https://doi.org/10.1111/j.1365-246X.2011.05327.x

61. Ling R.F. 1972. On the theory and construction of k-clusters. The Computer J., 15(4): 326-332. doi:10.1093/comjnl/15.4.326

62. Madariaga R. 1976. Dynamics of an expanding circular fault. Bull. of the Seismological Society of America, 66: 639-666.

63. Madariaga R. 1979. On the relation between seismic moment and stress drop in the presence of stress and strength heterogeneity. J. of Geophysical Research, 84: 2243-2250. https://doi.org/10.1029/jb084ib05p02243

64. Madariaga R. 2011. Earthquake scaling laws. In: R.A. Meyers, ed. Extreme environmental events: Complexity in forecasting and early warning. Springer, 364-383. https://doi.org/10.1007/978-1-4419-7695-6_22

65. McGarr A. 1993. Factors influencing the strong ground motion from mining-induced tremors. In: R.P. Young, ed. Rockbursts and seismicity in mines. Rotterdam, 3-12.

66. McGarr A. 1994. Some comparisons between mining-induced and laboratory earthquakes. Pure and Applied Geophysics, 142: 467-489.

67. Mori J., Abercrombie R.E., Kanamori H. 2003. Stress drops and radiated energies of aftershocks of the 1994 Northridge, California, earthquake. J. of Geophysical Research, 108(B11): 2545-2556. https://doi.org/10.1029/2001jb000474

68. Oth A., Parolai S., Bindi D., Wenz F. 2009. Source spectra and site response from S-waves of intermediate-depth Vrancea, Romania, earthquakes. Bull. of the Seismological Society of America, 99(1): 235-254. https://doi.org/10.1785/0120080059

69. Oye V., Bungum H., Roth M. 2005. Source parameters and scaling relations for mining-related seismicity within the Pyhäsalmi Ore Mine, Finland. Bull. of the Seismological Society of America, 95(3): 1011-1026. http://dx.doi.org/10.1785/0120040170

70. Pacor F., Spallarossa D., Oth A., Luzi L., Puglia R., Cantore L., Mercuri A., D’Amico M., Bindi D. 2016. Spectral models for ground motion prediction in the L'Aquila region (central Italy): evidence for stress-drop dependence on magnitude and depth. Geophysical J. International, 204(2): 697-718. https://doi.org/10.1093/gji/ggv448

71. Parolai S., Bindi D., Durukal E., Grosser H., Milkereit C. 2007. Source parameters and seismic moment-magnitude scaling for Northwestern Turkey. Bull. of the Seismological Society of America, 97(2): 655-660. https://doi.org/10.1785/0120060180 
72. Roecker S.W., Sabitova T.M., Vinnik L.P., Burmakov Y.A., Golvanov M.I., Mamatkanova R., Munirova L. 1993. Threedimensional elastic wave velocity structure of the Western and Central Tien-Shan. J. of Geophysical Research, 98(B9): 15779-15795. https://doi.org/10.1029/93jb01560

73. Ruff L.J. 1999. Dynamic stress drop of recent earthquakes: Variations within subduction zones. Pure and Applied Geophysics, 154: 409-431. https://doi.org/10.1007/s000240050237

74. Safonov D.A., Nagornykh T.V., Konovalov A.V., Stepnov A.A. 2017. The moment tensors, focal mechanisms, and stresses on Sakhalin Island. J. of Volcanology and Seismology, 11(3): 225-234. https://doi.org/10.1134/S0742046317030058

75. Sander J., Ester M., Kriegel H., Xu X. 1998. Density-Based Clustering in Spatial Databases: The Algorithm GDBSCAN and its applications. Data Mining and Knowledge Discovery, 2(2): 169-194. https://doi.org/10.1023/A:1009745219419

76. Sato T., Hirasawa T. 1973. Body wave spectra from propagating shear cracks. J. of Physics of the Earth, 21: 415-431. https://doi.org/10.4294/jpe1952.21.415

77. Shaw B.E., Richards-Dinger K., Dieterich J.H. 2015. Deterministic model of earthquake clustering shows reduced stress drops for nearby aftershocks. Geophysical Research Letters, 42: 9231-9238. https://doi.org/10.1002/2015gl066082

78. Scholz C.H. 2002. The mechanics of earthquakes and faulting. Cambridge: Cambridge Univ. Press, 496 p. https://doi.org/10.1017/cbo9780511818516

79. Scholz C.H. 2019. The mechanics of earthquakes and faulting. $3^{\text {rd }}$ ed. Cambridge: Cambridge Univ. Press, 519 p. https://doi.org/10.1017/9781316681473

80. Scuderi M.M., Marone C., Tinti E., Di Stefano G., Collettini C. 2016. Precursory changes in seismic velocity for the spectrum of earthquake failure modes. Nature Geoscience, 9(9): 695-700. https://doi.org/10.1038/ngeo2775

81. Tomic J., Abercrombie R.E., Do Nascimento A.F. 2009. Source parameters and rupture velocity of small $M \leq 2.1$ reservoir induced earthquakes. Geophysical J. International, 179: 1013-1023. https://doi.org/10.1111/j.1365-246x.2009.04233.x

82. Urbancic T.I., Young R.P. 1993. Space-time variations in source parameters of mining-induced seismic events with $M<0$. Bull. of the Seismological Society of America, 83: 378-397.

83. Yamada T., Mori J.J., Ide S., Abercrombie R.E., Kawakata H., Nakatani M., lio Y., Ogasawara H. 2007. Stress drops and radiated seismic energies of microearthquakes in a South African gold mine. J. of Geophysical Research, 112 , B03305. doi:10.1029/2006JB004553

84. Yunga S.L. 1990. Metody i rezul'taty izucheniya seysmotektonicheskikh deformatsiy [Methods and results of studies of seismotectonic deformations]. Moscow: Nauka, 191 p. (In Russ.). 